\title{
Influence of Organomineral Fertilizers Based on the Birch Bark and Inner Birch Bark on the Soil Properties
}

\author{
Evgeniya V. Veprikova ${ }^{a}$, Svetlana A. Kuznetsova ${ }^{a, b}$, \\ Nikolai V. Chesnokov ${ }^{\mathrm{a}, \mathrm{b}}$ and Olga A. Ulyanova ${ }^{\mathrm{c}}$ \\ anstitute of Chemistry and Chemical Technology SB RAS \\ FRC "Krasnoyarsk Science Center SB RAS" \\ 50/24 Akademgorodok, Krasnoyarsk, 660036, Russia \\ ${ }^{b}$ Siberian Federal University \\ 79 Svobodny, Krasnoyarsk, 660041, Russia \\ ${ }^{c}$ Krasnoyarsk Agricultural University \\ 90 Mira, Krasnoyarsk, 660049, Russia
}

Received 22.04.2016, received in revised form 18.06.2016, accepted 09.08.2016

\begin{abstract}
The properties of organomineral fertilizers obtained by urea deposit on the porous supports from birch bark and inner birch bark were investigated. It was determined that addition of the obtained organomineral fertilizers to soil increase humic acids and soluble microelements contend in its.
\end{abstract}

Keyword: organomineral fertilizers, porous supports, birch bark and inner birch bark, urea, humic acids. 


\title{
Влияние органоминеральных азотных удобрений на основе коры и луба березы на свойства почвы
}

\author{
Е.В. Веприкова ${ }^{a}$, С.А. Кузнецова ${ }^{\mathrm{a}, \tilde{\sigma}}$, \\ Н.В. Чесноков ${ }^{\text {a, }}$, О.А. Ульянова ${ }^{\text {в }}$ \\ ${ }^{a}$ Институт химии и химической технологии СО РАН \\ ФИЦ «Красноярский научный изентр СО РАН» \\ Россия, 660036, Красноярск, Академгородок, 50/24 \\ ${ }^{6}$ Сибирский федеральньий университет \\ Россия, 660041, Красноярск, пр. Свободный, 79 \\ ${ }^{8}$ Красноярский государственный аграрный университет \\ Россия, 660049, Красноярск, пр. Мира, 90
}

Изучены свойства органоминеральных удобрений, полученных нанесением мочевины на пористые подложки из коры и луба березы. Установлено, что внесение органоминеральных удобрений в почву приводит к увеличению содержания в ней гуминовых кислот и водорастворимых микроэлементов.

Ключевые слова: органоминеральные удобрения, пористые подложки, кора и луб березы, мочевина, гуминовые кислоты.

В настоящее время ведутся интенсивные исследования по получению ценных биологически активных веществ из коры березы, таких как бетулин, аллобетулин и других его производных, а также по использованию их в пищевой, химико-фармацевтической промышленности и ветеринарии [1-5]. Одним из наиболее эффективных способов утилизации отходов коры березы может стать их применение в качестве удобрения.

Обычной практикой в сельском хозяйстве является внесение в почву минеральных удобрений, что приводит к дополнительным потерям гумуса из-за повышения активности почвенной микрофлоры при недостатке органического вещества. Положительный баланс органического и минерального вещества в почве достигается при комплексном применении минеральных и органических либо органоминеральных удобрений [7-9]. Возможным способом приготовления комплексного органоминерального удобрения служит смешивание любых органических отходов: опилок, резаной соломы, торфа, лузги, измельченной древесной коры, отходов бумаги с формалином, мочевиной, фосфор- и калийсодержащими компонентами и целевой добавкой при определённом соотношении компонентов. Известно использование в качестве удобрения свежей коры сосны и лиственницы, а также коры, скопившейся в отвалах, не пригодных для сжигания. Кора, разлагаясь с выделением тепла, создает комфортные условия для жизнедеятельности растений, способствуя их развитию и росту, поэтому она может быть оценена как хороший кондиционер почвы [10].

Перспективным направлением утилизации коры берёзы может быть получение органоминеральных удобрений пролонгированного действия путем пропитки коры или луба берёзы 
водными растворами азот-, фосфор- и калийсодержащих минеральных солей или удобрений. После сушки такого удобрения мелкие частицы минеральных солей локализуются в порах и на поверхности органической подложки. Можно ожидать, что вследствие затрудненной диффузии минеральных солей из пор подложки из березовой коры в почву такие органоминеральные биокомпозитные удобрения будут обладать пролонгированным действием. Дозированное выделение минерального удобрения позволит исключить их передозировку в почве и повысить продолжительность их действия по сравнению с традиционными способами внесения удобрений. Со временем подложка из коры частично будет превращаться в гуминовые вещества под действием почвенной микрофлоры, что станет дополнительным фактором повышения урожайности сельскохозяйственных культур.

Целью работы являлось изучение свойств органоминеральных биокомпозитных удобрений на основе отходов коры березы в комплексе с мочевиной.

\section{Экспериментальная часть}

В качестве исходного сырья для получения биокомпозитных удобрений использовали кору и луб березы повислой (Betula pendula Rot.), заготовленные в окрестностях г. Красноярска. Сырье сушили при комнатной температуре до воздушно-сухого состояния и измельчали на дезинтеграторе марки Nossen (Германия).

Для получения биокомпозитных удобрений (БУ) фракционированную кору или луб березы обрабатывали 1,5\%-ным раствором $\mathrm{NaOH}$ при температуре $(80 \pm 5){ }^{\circ} \mathrm{C}$, гидромодуле 5 в течение 1 ч с последующей отмывкой водой и нейтрализацией остатков щелочи 2\%-ным раствором уксусной кислоты. Остатки кислоты удаляли промывкой водой до $\mathrm{pH}$ промывных вод 6-6,5. После отделения промывных вод материал сушили до воздушно-сухого состояния при $(50 \pm 5){ }^{\circ} \mathrm{C}$. Такая обработка позволяет удалить из коры и луба березы полифенольные соединения, отрицательно влияющие на рост растений, и приводит к развитию пористой структуры получаемого лигниносодержащего материала. Высокая пористость этих материалов будет способствовать водно-физическому улучшению почвы.

Затем пористые подложки (ПП) из коры или луба березы пропитывали водным раствором мочевины, объём которого был рассчитан исходя из влагоёмкости ПП. Концентрацию пропиточного раствора рассчитывали так, чтобы нанести 1,5 или 5,0 \% мас. азота на пористые подложки. Пропитку ПП проводили, добавляя раствор мочевины небольшими порциями и тщательно перемешивая. Затем влажные биокомпозитные удобрения помещали в закрытую посуду и выдерживали в растворе мочевины в течение суток при комнатной температуре. После пропитки мочевиной полученное органоминеральное биокомпозитное удобрение высушивали на воздухе до воздушно-сухого состояния.

Общее количество лигнина в образцах определяли по сернокислому способу в модификации Комарова, а содержание целлюлозы - по методу Кюршнера [11].

Для определения влияния биокомпозитных удобрений на основе луба и коры березы на свойства почвы (содержание гуминовых кислот и водорастворимых микроэлементов, $\mathrm{pH}$ почвы) были проведены лабораторные эксперименты на модельных смесях почвы с исследуемыми удобрениями. В работе использовали почву, отобранную в пригороде г. Красноярска, в соответствии с правилами отбора проб для анализа. Почву отделяли от растительных остатков 
и других инородных включений, истирали до фракции менее 1,0 мм и доводили до воздушносухого состояния в комнатных условиях. Почва имела следующие характеристики: $\mathrm{pH}_{\mathrm{KCL}} 6,5$; зольность 86,4 \%; влажность 2,8 \%; содержание гумуса 5,1 \%. Определение свойств почвы проводили по общепринятым методикам [12]. Содержание биокомпозитных удобрений в почве варьировало от 5 до $30 \%$ мас.

Смесь почвы и БУ увлажняли дистиллированной водой в соотношении 1:1. Выдерживали в плотно закрытой таре в течение 30 дней в статических условиях при температуре $(20 \pm$ 1) ${ }^{\circ} \mathrm{C}$, поддерживая влажность смеси на уровне 45-50\%. Параллельно аналогичным образом готовили контрольный образец почвы без удобрений. По истечении заданного времени к почвосмесям и контрольному образцу добавляли дистиллированную воду (в соотношении 1:10) с $\mathrm{pH} 5,4$ для извлечения водорастворимых гуминовых кислот. Выдерживали в течение 24 ч при периодическом перемешивании. Гуминовые кислоты выделяли подкислением фильтрата почвенной вытяжки соляной кислотой по методике ГОСТ 9517 - 94 . Аналогичным образом готовили почвенные смеси и их водные вытяжки для количественного определения в них микроэлементов ( $\mathrm{Fe}, \mathrm{Mn}, \mathrm{Mo}, \mathrm{B}, \mathrm{Cu}, \mathrm{Zn}, \mathrm{J})$. Определение количеств водорастворимых микроэлементов в почве проводили методом масс-спектрометрии на приборе ICP-MS 7500 Agilent.

Изменение значений рН почвы в присутствии БУ из луба и коры березы контролировали периодически в течение 60 сут. Для приготовления вытяжки почвосмеси обрабатывали $0,1 \mathrm{~N}$ раствором хлорида калия $\left(\mathrm{pH}_{\mathrm{KCL}}\right)$ согласно [12].

Вегетативные опыты по проращиванию семян яровой мягкой пшеницы сорта Новосибирская 15 проводили с использованием рулонов из фильтровальной бумаги согласно ГОСТу 12038-84 «Семена сельскохозяйственных культур: Методы определения всхожести». На увлажненные кипяченной охлажденной водой рулоны фильтровальной бумаги наносили 4 г БУ на основе подложки из луба, содержащего 5,0 \% мас. азота. Затем помещали на них по 60 штук семян и выдерживали в течение 7 дней при температуре $(23 \pm 2){ }^{\circ} \mathrm{C}$. В качестве контрольного варианта служила кипяченая водопроводная вода. По вариантам опыта определяли всхожесть, среднюю длину образовавшихся корней и ростков.

\section{Результаты и обсуждение}

Содержание лигнина в коре березы составляет 59,6 \% мас., в лубе - 42,5 \% мас.; содержание целлюлозы в коре березы составляет 15,8 \% мас., в лубе - 21,6 \% мас. В экстрактах бересты были обнаружены бетулин, лупеол и ростостимулирующие вещества $\beta$-ситостирол и фитостерин.

После пропитки коры или луба берёзы водным раствором мочевины и последующей сушки БУ мелкие частицы минеральных солей локализуются в порах и на поверхности коры или луба берёзы и вследствие затрудненной диффузии азота из пор березовой коры в почву обладают пролонгированным действием [13]. Дозированное выделение минерального удобрения позволяет исключить передозировку в почве и повысить продолжительность его действия по сравнению с традиционными способами внесения удобрений. Со временем подложка из коры частично будет превращаться в гуминовые вещества под действием почвенной микрофлоры, что явится дополнительным фактором повышения урожайности сельскохозяйственных культур.

$$
-261-
$$


Органическая легкоразлагаемая составляющая биокомпозитных удобрений из коры и луба березы после внесения в почву частично будет превращаться в гуминовые кислоты и возвращать утрачиваемые в процессе севооборота запасы гумуса. Высокая пористость биокомпозитных удобрений на основе коры и луба березы будет способствовать воднофизическому улучшению почвы, а биологически активные вещества - бетулин, лупеол и ростостимулирующие вещества $\beta$-ситостирол и фитостерин - окажут облагораживающее влияние на почву. Неорганическая составляющая данного удобрения - мочевина под влиянием уробактерий будет выделять фермент уреазу и разлагаться с образованием углекислого газа и аммиака; аммиак используется почвенными бактериями для биосинтеза белка.

Методами химического и рентгеноспектрального анализа, РЭМ, ЭПР, а также сорбционными авторами был изучен состав и строение биокомпозитных удобрений пролонгированного действия. Зарегистрировано наличие парамагнитных феноксирадикалов, ионов $\mathrm{Fe} 3+$ и $\mathrm{Mn} 2+$, ферромагнитных наночастиц $\mathrm{Fe}_{3} \mathrm{O}_{4}$, которые могут принимать участие в адсорбции мочевины на пористых подложках, установлено пролонгированное ростостимулирующее действие данных удобрений на примере кресс-салата [13].

На примере биокомпозитного удобрения на основе подложки из луба коры березы выявлено его позитивное влияние на прорастание семян яровой мягкой пшеницы сорта Новосибирская 15 (табл. 1).

Данные табл. 1 демонстрируют, что при проращивании семян пшеницы с применением БУ из луба наблюдается существенное увеличение длины ростков и корней по сравнению с контрольным опытом - в среднем в 1,5 и 1,4 раза соответственно.

Изменение содержания гуминовых кислот (ГК) в почве в зависимости от количества вносимых биокомпозитных удобрений из луба коры березы с содержанием азота 1,5 и 5 \% мас. представлено на рис. 1.

На рис. 1 видно, что увеличение количества вносимых в почву биокомпозитных удобрений на основе луба коры березы способствует увеличению содержания в ней гуминовых кислот (ГК). Наибольший эффект достигается при добавлении в почву БУ, содержащего 5 \% азота в форме мочевины. Содержание гуминовых кислот в почве через 30 сут после внесения $30 \%$ мас. этого биокомпозитного удобрения в 4 раза превышает содержание гуминовых кислот в почве без удобрений и в 2,2 раза в присутствии биокомпозитного удобрения с более низким содержанием азота (1,5\% мас.).

Таблица 1. Влияние биокомпозитного удобрения (БУ) на прорастание семян яровой мягкой пшеницы сорта Новосибирская 15

\begin{tabular}{|l|c|c|c|c|}
\hline \multicolumn{1}{|c|}{ Вариант опыта } & $\begin{array}{c}\text { Длина ростка, мм } \\
\mathrm{X} \pm \mathrm{Sx}\end{array}$ & $\begin{array}{c}\text { Коэффициент } \\
\text { вариации, \% }\end{array}$ & $\begin{array}{c}\text { Длина корней, мм } \\
\mathrm{X} \pm \mathrm{Sx}\end{array}$ & $\begin{array}{c}\text { Коэффициент } \\
\text { вариации, \% }\end{array}$ \\
\hline Вода - контроль & $60 \pm 4$ & 44 & $76 \pm 3$ & 48 \\
\hline $\begin{array}{l}\text { БУ из луба березовой } \\
\text { коры (5,0\% мас. азота) }\end{array}$ & $92 \pm 2$ & 16 & $103 \pm 2$ & 32 \\
\hline
\end{tabular}

Примечание. $\mathrm{X}$ - среднее значение; $\mathrm{Sx}$ - стандартная ошибка среднего. 


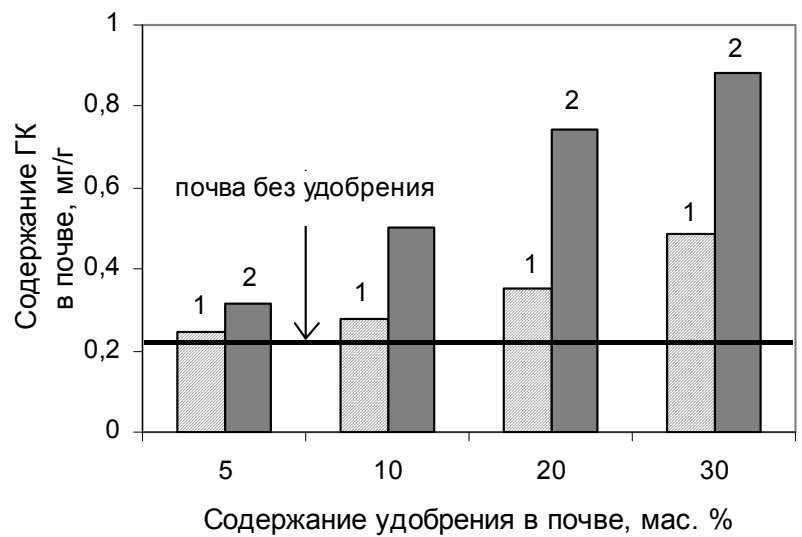

Рис. 1. Влияние содержания в почве биокомпозитного удобрения из луба коры березы на содержание гуминовых кислот: 1 - удобрение, содержащее 1,5 \% азота; 2 - удобрение, содержащее 5 \% азота. Время выдержки смеси почвы с удобрением 30 сут

Было установлено, что в случае внесения в почву удобрения из березового луба, содержащего $5 \%$ азота, в количестве 20 и $30 \%$ мас. увеличение ГК в почве наблюдается уже через 10 сут (до 0,27 и 0,32 мг/г соответственно).

Поскольку гуминовые кислоты в малых количествах являются мощным биостимулятором роста растений, то увеличение их количества в почве в присутствии исследуемых биокомпозиционных удобрений усиливает наблюдаемое ранее влияние мочевины на рост кресссалата [13].

Известно, что микроэлементы необходимы для нормального роста и развития растений. Причем присутствие в почве микроэлементов в водорастворимой форме очень важно, так как в этой форме они наиболее быстро усваиваются растениями $[12,14]$, поэтому проведены исследования по изучению влияния биокомпозитных удобрений на основе березового луба с мочевиной, содержащих 1,5 \% азота, на содержание микроэлементов в почве (табл. 2).

Данные, представленные в табл. 2, показывают, что азотсодержащие удобрения из луба обеспечивают увеличение водорастворимых микроэлементов в почве, за исключением марганца. С увеличением количества удобрения, внесенного в почву, увеличивается содержание водорастворимых микроэлементов. Следует отметить, что применение удобрения из луба в количестве 10 мас. \% приводит к значительному увеличению в почве железа (в 1,7 раза), молибдена (1,4 раза), меди (в 7,0 раз), цинка (5,1 раза) и йода (1,9 раза). Таким образом, применение исследуемых биокомпозитных удобрений из луба берёзы с мочевиной увеличивает содержание в почве микроэлементов в водорастворимых формах.

Важным свойством любого удобрения является кислотность почвы, которая создается после их внесения. В табл. 3 приведены данные динамики изменения $\mathrm{pH}_{\mathrm{KCL}}$ почвы после внесения в нее биокомпозитных удобрений из луба и коры березы с мочевиной при исследовании кислотности почвы от 2 до 60 сут.

По данным табл. 3 видно, что кислотность почвы мало изменяется в результате внесения удобрения из луба коры березы. По значению $\mathrm{pH}_{\mathrm{KCL}}$ почву в присутствии этого удобрения мож-

$$
-263-
$$


Таблица 2. Влияние биокомпозитных удобрений на основе луба коры березы с мочевиной на содержание водорастворимых микроэлементов в почве

\begin{tabular}{|c|c|c|c|}
\hline \multirow{2}{*}{ Микроэлемент } & \multicolumn{3}{|c|}{ Содержание водорастворимого микроэлемента в почве, мкг/ 100 г почвы } \\
\cline { 1 - 4 } & Почва & $\begin{array}{c}\text { Почва с добавлением 5 \% мас. } \\
\text { БУ из луба с мочевиной }\end{array}$ & $\begin{array}{c}\text { Почва с добавлением } 10 \text { \% мас. } \\
\text { БУ из луба с мочевиной }\end{array}$ \\
\hline Железо & 330,0 & 380,0 & 570,0 \\
\hline Марганец & 12,0 & 12,0 & 13,0 \\
\hline Молибден & 79,0 & 87,0 & 110,0 \\
\hline Бор & 150,0 & 180,0 & 190,0 \\
\hline Медь & 9,8 & 35,0 & 69,0 \\
\hline Цинк & 3,5 & 9,3 & 18,0 \\
\hline Йод & 40,0 & 68,0 & 74,0 \\
\hline
\end{tabular}

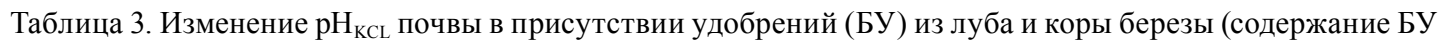
в почве $10 \%$; содержание в них азота $1,5 \%$ мас.)

\begin{tabular}{|c|c|c|c|c|c|}
\hline \multirow{2}{*}{ Удобрение } & \multicolumn{4}{|c|}{$\mathrm{pН}_{\text {ксL почвы в присутствии биокомпозитных удобрений }}$} \\
\cline { 2 - 6 } & 2 сут & 4 сут & 10 сут & 30 сут & 60 сут \\
\hline Нет & $6,5 \pm 0,1$ & $6,5 \pm 0,1$ & $6,4 \pm 0,1$ & $6,6 \pm 0,2$ & $6,6 \pm 0,2$ \\
\hline БУ из луба коры березы & $6,3 \pm 0,1$ & $6,3 \pm 0,1$ & $6,5 \pm 0,1$ & $6,6 \pm 0,2$ & $6,8 \pm 0,2$ \\
\hline БУ из коры березы & $6,2 \pm 0,1$ & $6,1 \pm 0,1$ & $6,0 \pm 0,1$ & $6,2 \pm 0,1$ & $6,3 \pm 0,1$ \\
\hline
\end{tabular}

но отнести в слабокислым, близким к нейтральным. Почва с удобрением из коры березы имеет большую кислотность уже через 10 сут. В течение 60 сут кислотность уменьшается мало, и по значению $\mathrm{pH}_{\mathrm{KCL}}$ такую почвосмесь можно отнести к слабокислым [12]. Как показывают данные табл. 1 , в течение исследованного времени кислотность почвы изменяется в достаточно узком интервале - от 6,2 до 6,8. Известно, что такое изменение не может существенно повлиять на свойства почвы, зависящие от ее рН (емкость поглощения, степень ионизации функциональных групп, образование гидроокисей и др.) [14].

Комплекс позитивных изменений свойств почвы в присутствии азотсодержащих биокомпозитных удобрений на основе луба и коры березы (увеличение количества гуминовых кислот и водорастворимых микроэлементов) при незначительном изменении $\mathrm{pH}$ может, вероятно, усиливать отмеченное в работе [13] пролонгированное действие входящего в их состав азота.

\section{Заключение}

Показано, что внесение в почву органоминеральных биокомпозитных удобрений, содержащих мочевину в порах подложек из коры и луба берёзы, приводит к увеличению содержания в ней гуминовых кислот и водорастворимых микроэлементов. Установлено, что эти удобрения способствуют позитивным изменениям свойств почвы, проявляющихся в увеличении количества гуминовых кислот и водорастворимых микроэлементов при незначительном изменении pH, а также обладают пролонгированным действием. 


\section{Список литературы}

1. Patent 2013117137 WO. Lu, F. Preparation of lupane triterpenoid derivatives and pharmaceutical use thereof for the treatment of HIV-1/AIDS PCT Int. Appl. Publ. Date 15.08.2013.

2. Lee S., Jung K., Lee D. et al. Protective effect and mechanism of action of lupane triterpenes fromCornuswalteri in cisplatin-induced nephrotoxicity. Bioorg Med Chem Lett. 2015. Vol. 25(23). P. 5613-5618.

3. Shakhtshneider, T. P., Kuznetsova, S. A., Mikhailenko, M. A., Zamai, A. S., Malyar, Yu. N., Zamai, T. N., Boldyrev, V. V. Effect of mechanochemical treatment on physicochemical and antitumor properties of betulin diacetate mixtures with arabinogalactan. Chemistry of Natural Compounds. 2013. V. 49. 470-474.

4. Alakurtti S., Heiska T., Kiriazis A., Sacerdoti-Sierra N., Jaffe C.L., Yli-KauhaluomaJ. Synthesis and anti-leishmanial activity of geterocyclic betulin derivatives. Bioorganic \& Medicinal Chemistry. 2010. Vol. 18. Issue 4. P. 1573-1582.

5. Salin O., Alakurtti S., Pohjala L., Siiskonen A., Maass V., Maass M., Yli-Kauhaluoma J., VuorelaP.Inhibitory effect of the natural product betulin and its derivatives against the intracellular bacterium Chlamydia pneumoniae. Biochemical Pharmacology. 2010. Vol. 80. Issue 8. P. 1141-1151.

6. Петрова К.В., Позднякова В.Ф., Щеголев П.О., Пологно С.А., Кузьменков Н.Н. Влияние коры березы измельченной на биохимический состав крови телят. Вопросы нормативноправового регулирования в ветеринарии. 2010. № 2. C. 33-35. [Petrova K.V., Pozdnjakova V.F., Schegolev P.O., Pologno S.A., Kuzmenko N.N. Vliyanie kori berezi izmelchennoi na biohimichescii sostav krovi telyat. Voprpsi pravovogo regulirovaniya v veterinarii.2010. № 2. P. 33-35. (in Russ.) ]

7. Патент 2496752 РФ. Червонобаб Н.Л. Способ получения органоминерального удобрения пролонгированного действия (варианты). Опубл. 27.10.2013. [Patent 2496752 RU. Chervonobab N.L. Sposob polucheniya opganomineralnogo udobreniya prolongirovannogo deistviya. Publ. Date 27.12.2013. (in Russ.)]

8. Патент 2318783 РФ. Ефанов М.В., Галочкин А.И., Петраков А.Д., Сграбилова Л.С., Новоженов В.А. Способ получения азотсодержащих органических удобрений на основе лигноуглеводных материалов. Опубл. 10.03.2008.[Patent 2318783 RU. Efanov M.V., Galochkin A.I., Petrakov A.D., Sgrabilova L.S. Sposob polucheniya azotsoderjasctih organicheskih udobrenii na osnove lignouglevodnih materialov. Publ. Date 10.03.2008. (in Russ.)]

9. Патент 2092468 РФ. Тарханова Л.С., Тарханов О.В., Тарханов А.О., Тарханнов В.О. Способ получения органоминеральных удобрений. Опубл.10.10.1997.[Patent 2092468 RU. Tarhanova L.S., Tarhanov O.V., Tarhanov A.O., Tarhanov V.O. Sposob polucheniya opganomineralnih udobrenii. Publ. Date. 10.10.1997. (in Russ.)]

10. Дейнеко И.П., Нгует Н.Т.М., Дейнеко И.В., Корнилова Л.И. Изучение окислительного аммонолиза сосновой коры. Химия растительного сырья. 2007. № 3. C.13-19. [Deineko I.P., Nguet N.T.M., Deineko I.V., Kornilova L.I. Izuchenie okislitelnogo ammonoliza sosnovoi kori. Khimiya rastitelnogo sirya. 2007. № 3. P.13-19. (in Russ.)]

11. Оболенская А.В., Ельницкая 3.П., Леонович А.А. Лабораторные работы по химии древесины и целлюлозы. М.: Экология, 1991. С. 96-107. [ Obolenskaya A.V., Elnitskaya Z.P., Leonovich A.A. Laboratornie raboti po khimii drevesini i tsellylozi. M.: Ekologiya. 1991. P. 96 107. (in Russ.)] 
12. Котова Д.Л., Девятова Т.А., Крысанова Т.А., Бабенко Н.К., Крысанов В.Л. Методы контроля качества почвы. Воронеж: Изд-во ВГУ, 2007. 106 с. [Kotova D.L., Devyatova T,A, Krisanova T.A., Babenko N.K., Krisanov V.L. Metodi kontrolya kachestva pochvi. Voronej: Izd-vo VGU, 2007. 106 c. (in Russ.)]

13. Кузнецова С.А., Кузнецов Б.Н., Скурыдина Е.С., Максимов Н.Г., Калачева Г.С., Ульянова О.А., Скворцова Г.П. Синтез и свойства биокомпозитных удобрений на основе мочевины и коры березы. Журнал сибирского федерального университета. Химия. 2013. Т. 6 (4). С. 380 - 393. [Kuznetsova S.A., Kuznetsov B.N., Skurydina E.S., Maksimov N.G., Kalachova G.S, Ulyanova O.A., Skvortsova C.P. Synthesis and properties of biocomposite fertilizers on the basis of urea and birch bark. Journal of Suberian Federal University. Chemistry. 2013. V. 6 (4). P. 380 - 393. (in Russ.)]

14. Орлов Д.С. Химия почв. М.: Изд-во МГУ, 1992. 400 с.[ Orlov D.S. Khimiya pochv. M.: Izd-vo MSU. 1992. 400 p. (in Russ.)] 